\title{
PENGARUH BUDAYA ORGANISASI SEKOLAH, KOMPETENSI GURU DAN MOTIVASI GURU TERHADAP KINERJA GURU DI SMA NEGERI KECAMATAN SAMALANGA KABUPATEN BIREUEN
}

\author{
Muntasir $^{1)}$ dan M. Yusuf A. Samad ${ }^{2 *}$ \\ 1,2 Dosen FE Universitas Islam Kebangsaan Indonesia \\ *) email: m.yusuf@uniki.ac.id
}

DOI:

https://doi.org/10.55178/idm.v2i3.211

ABSTRAK

Article history

Received:

March 10, 2021

Revised:

March 15, 2021

Accepted:

March 18, 2021

Page:

$21-31$

\section{Kata kunci:}

Budaya Organisasi,

Kompetensi,

Motivasi guru,

Kinerja guru
Tujuan penelitian ini adalah untuk mengetahui a) pengaruh budaya organisasi sekolah terhadap kinerja guru, b) pengaruh kompetensi guru terhadap kinerja guru, c) pengaruh motivasi guru terhadap kinerja guru, dan d) pengaruh faktor-faktor budaya organisasi, kompetensi guru, dan motivasi guru terhadap kinerja guru SMA Negeri se-Kecamatan Samalanga Kabupaten Bireuen. Objek penelitian adalah 50 guru PNS (ASN) yang bekerja sebagai guru di SMA Negeri se-Kecamatan Samalanga Kabupaten Bireuen tahun 2020. Dengan metode kuantitatif, dan teknik analisi menggunakan model analisis jalur. Hasil penelitian menunjukkan; 1) Budaya organisasi yang telah dijalankan di sekolah SMA Negeri Kecamatan Samalanga Kabupaen Bireuen, menurut persepsi guru sudah berjalan baik dalam mendukung kinerja guru. Penilaian guru atas budaya sekolah mencapai $87,87 \%$ telah disesuai dengan harapan guru. Sementara itu tingkat Kompetensi guru yang profesional, sesuai dengan Peraturan Pemerintah No.74 tahun 2008, sudah baik mencapai 85,83\% dari kondisi yang ideal. Dan motif guru untuk berprestasi, afiliasi dan kekuasaan dalam mendukung program sekolah yakni peningkatan mutu menunjukkan hal yang baik, mencapai $85,13 \%$ dari yang diharapkan. Dan tingkat kinerja guru dalam melaksanakan perencanaan pembelajaran, Pelaksanaan KBM maupun melakukan evaluasi hasil belajar sudah mencapai kategori sangat baik, yakni 85,83\% dari target tugas yang ideal. 2) Hasil penelitian verifikatif didasarkan analisis kausalitas antar variabel membuktikan; a) terdapat pengaruh yang signifikans budaya sekolah terhadap Kinerja guru, mencapai $25,06 \%$. b) pengaruh kompetensi guru terhadap Kinerja guru, sebesar $50,52 \%$. c) pengaruh motivasi guru untuk berprestsi dan berafiliasi terhadap Kinerja guru, sebesar 18,09 \%, dan d) secara bersama-sama pengaruh Budaya Organisasi, Kompetensi dan Motivasi guru, terhadap Kinerja guru diperoleh dari nilai determinasi antar variabel ini, yakni sebesar $62,6 \%$.

\section{Pendahuluan (Introduction)}

Sumber daya manusia disekolah tidak lain adalah para guru dan karyawan yang ada disekolah, serta siswa dan masyarakat sekitar. Seorang kepala sekolah harus mempunyai kemampuan untuk mengelola mereka agar efektif dan efisien, seorang kepala sekolah juga harus mampu menciptakan kondisi kerja yang kondusif untuk semua unsur. Guru adalah figur manusia sumber yang menempati posisi dan memegang peranan penting dalam pendidikan. Ketika semua orang mempersoalkan masalah dunia pendidikan, figur guru mesti terlibat dalam agenda pembicaraan, terutama yang menyangkut persoalan pendidikan formal disekolah. Karena itu guru sebagai pelaku utama pendidikan.

Peran sekolah yang merupakan lembaga pendidikan nasional dalam rangka mewujudkan tujuan nasional dituntut mampu melaksanakan proses kegiatan belajar mengajar dengan tertib, terarah dan berkesinambungan. Jabatan guru sebagai pendidik merupakan jabatan profesional dituntut untuk terus berkembang sesuai dengan perkembangan zaman, ilmu pengetahuan dan teknologi. Pendidikan yang bermutu dan berkualitas diharapkan dapat meningkatkan kualitas sumber daya manusia Indonesia sehingga diharapkan mampu menghadapi persaingan dengan negara lain dimasa depan. 
Peran sekolah tidak hanya bersaing dalam hal akademik melalui prestasi sekolah maupun akreditasi, namun juga bersaing dalam mutu pendidikan yang baik untuk menarik minat calon siswa. Namun permasalahan yang sering dihadapi yaitu masih adanya keraguan masyarakat terhadap kinerja guru yang tinggi akibat budaya organisasi di sekolah, kompetensi guru dan motivasi guru sekolah di SMA Negeri di Kecamatan Samalanga.

Meninjau data statistik yang diterbitkan oleh Dinas Pendidikan Aceh, Kabupaten Bireuen masih belum menggembirakan, hanya berada di ranking ke-18 dari perolehan nilai UN (Ujian Nasional) yang dilaksanakan berbasis Komputer pada bulan April 2019 lalu. Dan hasil ini hanya naik 1 (satu) peringkat dari tahun sebelumnya 2018. Dan kategori Akreditasi jenjang SMA, tidak semua sekolah terdapat Akreditasi-A pada SMA di wilayah Kecamatan Samalanga.

Sedangkan dalam 10 peringkatan SMA terbaik di Aceh tahun 2019, tidak terdapat satupun yang berasal dari Kabupaten Bireuen, sebagaimana dirilis dalam situs: https://www.ceritabumi.com/sma-terbaik-aceh tertanggal 30 Maret 2019. Adapun 10 peringkat terbaik tersebut adalah: 1. SMA Negeri 10 Fajar Harapan Banda Aceh, 2. SMA Negeri 2 Modal Bangsa Aceh Besar, 3. SMAN Modal Bangsa Arun Lhoksemawe, 4. SMA Swasta Fatih Bilingual Boarding School Banda Aceh, 5. SMA Negeri 2 RSBI Banda Aceh, 6. SMA Negeri 4 Banda Aceh, 7. SMA Negeri 3 Banda Aceh, 8. SMA Negeri 4 Wira Bangsa Aceh Barat, 9. SMA Negeri 4 Takengon Aceh Tengah, dan 10. SMA Unggul Tapaktuan Aceh Selatan.

Sekolah mempunyai sebuah karakteristik yang dianut sebagai pedoman dalam melakukan organisasi. Hal ini menunjukkan kinerja guru sangat penting untuk kemajuan organisasi. Kemajuan organisasi akan lancar apabila kinerja yang diberikan guru maksimal. Kinerja guru adalah kemampuan dan keberhasilan guru dalam melaksanakan tugas-tugas pembelajaran yang ditunjukkan oleh indikatorindikator: (1) kemampuan menyusun rencana dan program pembelajaran; (2) kemampuan melaksanakan pembelajaran; (3) kemampuan mengadakan hubungan antara pribadi; (4) kemampuan melaksanakan penilaian; (5) kemampuan melaksanakan program pengayaan; dan (6) kemampuan melaksanakan program remedial. (Supardi, 2013:40) Kinerja guru dipengaruhi oleh faktor internal dan eksternal. Sebagaimana Mulyasa (2007:227) menyatakan faktor internal yaitu dorongan untuk bekerja, tanggung jawab terhadap tugas, minat terhadap tugas. Faktor eksternal yaitu penghargaan atas tugas, peluang untuk berkembang, perhatian dari kepala sekolah, hubungan interpersonal sesama guru, adanya pelatihan, kelompok diskusi terbimbing, dan layanan perpustakaan.

Sebuah karakteristik yang harus dijunjung tinggi oleh organisasi dan menjadi panutan organisasi sebagai pembeda antara satu organisasi dengan organisasi yang lain adalah budaya organisasi. Budaya organisasi juga diartikan sebagai nilai-nilai dan norma perilaku yang diterima dan dipahami secara bersama oleh anggota organisasi sebagai dasar dalam aturan perilaku yang terdapat dalam organisasi tersebut.

Jika organisasi mengalami perkembangan maka organisasi akan meraih kesuksesan, visi, serta pendiri akan dipandang sebagai faktor penentu utama kesuksesan. Kesuksesan sebuah organisasi juga dilihat dari anggota dan semua orang yang membantu organisasi.

Suatu budaya organisasi memberikan ilham bagi orang-orang yang berada dalam organisasi tersebut untuk memahami bagaimana cara mereka bekerja di lingkungannya (Amir, 2014). Suatu organanisasi terdapat orang yang membantu kesuksesan organisasi tersebut. Dalam hal ini, guru merupakan orang yang dapat mensukseskan suatu organisasi.

Peneliti masih menemukan permasalahan yang serius dalam menciptakan budaya organisasi sekolah yang kondusif, sehingga dapat mendukung kinerja guru, dan prestasi siswa, baik secara akademik ataupun secara non akademik (minat bakat misalnya). Hasil UN tahun 2019 lalu, tidak terdapat siswa SMA Negeri yang berasal dari Kecamatan Samalanga yang menonjol prestasinya, walaupun lulus UN meningkat sampai 88 persen, namun tidak ada yang menduduki rangking 20 besar se- Kabupaten Bireuen.Masih di dominasi dari SMAN favorit di Bireuen, seperti SMAN 1 dan 2 Bireuen.

Disamping itu juga peneliti menemukan budaya organisasi sekolah kaitannya dengan Visi dan misi sekolah belum dipahami oleh seluruh guru-guru SMA Negeri di Kecamatan Samalanga Kabupaten Bireuen, berdampak pada kinerjanya belum mencirikan apa yang diharapkan dalam Visi dan Misi sekolah. Juga lingkungan kerja yang kurang kondusif, yang berakibat langsung dengan kurang nyamannya guru-guru dalam bekerja secara tertib dan optimal.

Seorang guru harus mempunyai kompetensi. Kompetensi guru dipengaruhi oleh motivasi. Kompetensi pedagogik merupakan salah satu kompetensi yang harus dimiliki seorang guru. Dalam hal ini, guru harus mampu menguasai karakteristik siswa, menguasai teori belajar dan prinsip-prinsi pembelajaran yang 
mendidik. Dalam hal ini, guru juga dituntut untuk mengembangkan kurikulum. Pengembangan kurikulum yang dilakukan guru haru mampu menghasilkan pembelajaran yang inovatif, dan bermakna. Penguasaan kompetensi erat kaitannya dengan kemampuan guru melakukan pembalajaran. kompetensi ini sebagai bagian penting dari tugas utama guru.

Selain itu, motivasi guru juga merupakan faktor penting yang dibutuhkan dalam meningkatkan kinerja di bawah naungan budaya organisasi. Pemberian motivasi yang tepat akan mendorong pegawai merubah perilakunya untuk tumbuh dan berkembang mencapai keberhasilannya dalam bekerja. Output utama yang dihasilkan adalah peningkatan kinerja guru dalam sebuah organisasi. Dalam hal ini, kepala sekolah sebagai pemimpin harus mampu mendorong guru untuk melakukan meningkatkan kinerjanya melalui kompetensi guru, motivasi guru yang dimiliki dan budaya organisasi sekolah yang dianut.

Kinerja guru adalah prestasi seorang guru dalam merealisasikan perannya sebagai seorang guru. Peran guru dalam pendidikan menunjukkan prestasi dalam kinerjanya. Kinerja guru adalah kegiatan guru dalam proses pembelajaran, melaksanakan kegiatan pembelajaran, dan menilai hasil belajar (Dirjen PMPTK Depdiknas, 2008).

Berdasarkan observasi awal yang dilakukan pada bulan Juli 2019, SMA Negeri Kecamatan Samalanga Kabupaten Bireuen yang terdiri dari 3 sekolah. Temuan dari hasil observasi tersebut adalah dilihat dari kinerjanya guru-guru SMA Negeri Kecamatan Samalanga Kabupaten Bireuen kurang optimal, dikarenakan masih ada guru belum menguasai sepenuhnya materi yang diajarkan dimungkinkan karena profesionalitas guru tersebut memang masih kurang.

Berdasarkan observasi awal yang dilakukan pada bulan Juli 2019, SMA Negeri Kecamatan Samalanga Kabupaten Bireuen yang terdiri dari 3 sekolah. Temuan dari hasil observasi tersebut adalah dilihat dari kinerjanya guru-guru SMA Negeri Kecamatan Samalanga Kabupaten Bireuen kurang optimal, dikarenakan masih ada guru belum menguasai sepenuhnya materi yang diajarkan dimungkinkan karena profesionalitas guru tersebut memang masih kurang.

Berdasarkan uraiakan yang telah disampaikan peneliti, maka perlu dilakukan penelitian yang mendalam tentang hal tersebut dengan dalam pembuatan tesis yang diberi judul "Pengaruh Budaya Organisasi Sekolah, Kompetensi Guru dan Motivasi Guru Terhadap Kinerja Guru di SMA Negeri Kecamatan Samalanga Kabupaten Bireuen".

\section{Tinjauan Literatur (Literature Review)}

\section{a. Pengaruh Budaya Organisasi Sekolah dengan Kinerja Guru}

Menurut Colquitt (2004:546), "budaya organisasi adalah pembagian pengetahuan sosial dalam sebuah organisasi termasuk aturan, norma, dan nilai yang membentuk sikap, dan tingkah laku para pekerjanya".Menurut Mas'ud dalam Mariam (2009:38), "budaya organisasi adalah sistem makna, nilainilai, dankepercayaan yang dianut bersama dalam suatu organisasi yang menjadi rujukan untuk bertindak, dan membedakan organisasi satu dengan organisasi lain". Menurut Luthan (2011:72), ada enam karakteristik budaya organisasi, antara lain : a. Observed behavioral regularities adalah keberaturan cara bertindak dari para anggota lainnya, mereka mungkin menggunakan bahasa umum, istilah atau ritual tertentu. b. Norm, yakni berbagai standar perilaku yang ada, termasuk di dalamnya tentang pedoman sejauh mana suatu pekerjaan yang harus dilakukan. c. Dominant value, yakni adanya nilai-nilai inti yang dianut bersama oleh seluruh anggota organisasi. d. Philosophy, yakni adanya kebijakan-kebijakan yang berkenaan dengan keyakinan organisasi dalam memperlakukan setiap anggota organisasinya dalam memperlakukan pelanggan karyawan. e. Rules, yaitu adanya pedoman ketat, dikaitkan dengan kemajuan organisasi. f. Organization Climate, yakni perasaan keseluruhan (an overall feeling) yang tergambar, dan disampaikan melalui kondisi tata ruang, cara berinteraksi para anggota organisasi, dan cara interaksi anggota organisasi kepada pelanggan atau orang lain.

Menurut Tanadi Santono dalam Asri Laksmi Riani (2011: 109) bahwa: "Budaya perusahaan bukanlah sekadar peraturan tertulis, dasar operasional, atau sistematika kerja yang menjadi buku suci perusahaan. Lebih dari itu, budaya perusahaan adalah spirit d'corp atau jiwa perusahaan, yang menjiwai keseharian dan segala aktivitas dalam perusahaan. Sangat ditekankan pentingnya budaya perusahaan yang menjadi dasar dari kinerja perusahaan agar mampu berkembang dan bersaing dalam jangka panjang.

Faktor lain yang mendukung kinerja guru dalam suatu organisasi atau lembaga pendidikan adalah kompetensi, karena dengan kompetensi yang baik maka semua tugas yang dibebankan terhadap individu akan dapat diselesaikan secara maksimal sesuai dengan kompetensi yang dimilikinya. Sedangkan 
kompetensi guru adalah kumpulan dari pengetahuan, keterampilan, serta sikap yang ditampilkan dalam bentuk perilaku cerdas dan penuh tanggung jawab dalam menjalankan profesinya.

\section{b. Pengaruh Kompetensi Guru dengan Kinerja Guru}

Menurut Dreyfus, dan Deyfus dalam Saifudin (2004:25), "kompetensi adalah keahlian seorang yang berperan secara berkelanjutan yang mana pergerakannya melalui proses pembelajaran, dari "pengetahuan sesuatu" ke "mengetahui bagaimana", seperti misalnya : dari sekedar pengetahuan yang tergantung pada aturan tertentu kepada suatu pertanyaan yang bersifat intuitif'. Menurut Boyatzis dalam Saifudin (2004:30), "kompetensi adalah kapasitas yang ada pada seseorang yang bisa membuat orang tersebut mampu memenuhi apa yang disyaratkan oleh pekerjaan dalam suatu organisasi sehingga organisasi tersebut mampu mencapai hasil yang diharapkan".

Menurut Semiawan (2011:45), ada empat kompetensi yang harus dimiliki oleh guru, antara lain : a. Kompetensi pedagogik ialah kemampuan dalam pengelolaan peserta didik yang meliputi : pemahaman wawasan atau landasan kependidikan, pemahaman terhadap peserta didik, pengembangan kurikulum/silabus, perancangan pembelajaran, pelaksanaan pembelajaran yang mendidik dan dialogis, evaluasi hasil belajar, dan pengembangan peserta didik untuk mengaktualisasi berbagai potensi yang dimiliknya. b. Kompetensi kepribadian, yakni menciptakan kepribadian, yang : mantap, stabil, dewasa, arif dan bijaksana, berwibawa, berakhlak mulia, menjadi teladan bagi peserta didik dan masyarakat, mengevaluasi kinerja sendiri, dan mengembangkan diri secara berkelanjutan. c. Kompetensi sosial ialah kemampuan pendidik sebagai bagian dari masyarakat, untuk : berkomunikasi lisan dan tulisan, menggunakan teknologi informasi dan komunikasi secara fungsional, bergaul secara efektif dengan peserta didik, dan bergaul secara santun dengan masyarakat sekitar. d. Kompetensi profesional ialah kemampuan penguasaan materi secara luas, dan mendalam yang meliputi : konsep struktur dan metode keilmuan/teknologi/seni yang menaungi koheren dengan materi ajar, materi ajar yang ada dalam kurikulum sekolah, hubungan konsep antar pelajaran terkait, penerapan konsep-konsep keilmuan dalam kehidupan sehari-hari, dan kompetensi secara profesional dalam konteks global dengan tetap melestarikan nilai, dan budaya nasional.

Menurut Keith Davis dalam Mangkunegara (2007:67) bahwa : "Faktor yang mempengaruhi kinerja ada dua yaitu kemampuan (ability) dan motivasi (motivation)". Menurut Gibson yang dikutip oleh Ilyas (1999: 57), yang mengemukakan bahwa: "Untuk mencapai kinerja yang baik ada tiga kelompok variabel yang mempengaruhi perilaku kerja dan kinerja yaitu : Pertama, varibel individu, yang meliputi : kemampuan dan keterampilan; latar belakang keluarga, tingkat sosial, pengalaman, umur, etnis, jenis kelamin; Kedua, variabel organisasi, yang mencakup antara lain: sumber daya; kepemimpinan; imbalan; struktur; desain pekerjaan; Ketiga, variabel psikologis, yang meliputi: persepsi; sikap; kepribadian; belajar; dan motivasi”.

Penelitian dari Muhammad Rizal Saragih menyatakan bahwa kompetensi guru berpengaruh secara parsial terhadap kinerja guru SDN Joglo 05 Pagi Jakarta.

\section{c. Pengaruh Motivasi Guru dengan Kinerja Guru}

Menurut Robbins (2008:229), motivasi adalah proses yang menjelaskan intensitas, arah, dan ketekunan seorang individu untuk mencapai tujuannya. Hubungan antara motivasi, dan intensitas, intensitas terkait dengan seberapa giat seseorang berusaha, tetapi intensitas tinggi tidak menghasilkan prestasi kerja yang memuaskan kecuali upaya tersebut dikaitkan dengan arah yang menguntungkan organisasi, sebaliknya elemen yang terakhir, ketekunan, merupakan ukuran mengenai berapa lama seseorang dapat mempertahankan usahanya. Sedangkan menurut Siagian dalam Agustini (2012:37), motivasi adalah daya dorong yang mengakibatkan seseorang anggota organisasi mau, dan rela mengarahkan kemampuan dalam bentuk keahlian dan ketrampilan, tenaga dan waktunya untuk menyelenggarakan berbagai kegiatan yang menjadi tanggung jawabnya, dan menunaikan kewajibannya dalam rangka pencapaian tujuan, dan berbagai sasaran organisasi yang telah ditentukan sebelumnya. Menurut McClleland dalam Saputra (2008:11), mengelompokkan tiga kebutuhan manusia yang dapat memotivasi gairah bekerja, yaitu : a. Need for Achievement (Kebutuhan berprestasi). Need for achievement adalah kebutuhan untuk berprestasi sebagai refleksi dari dorongan akan tanggung jawab untuk memecahkan suatu masalah. Seorang pegawai yang mempunyai kebutuhan akan prestasi tinggi cenderung untuk berani mengambil resiko. b. Need For Affiliation (Kebutuhan diterima oleh orang lain). Need For Affiliation adalah kebutuhan berinteraksi dengan orang lain, bekerjasama dengan orang lain, dan tidak mau melakukan sesuatu yang merugikan orang lain. c. Need of Power (Kebutuhan kekuasaan). Need of Power adalah kebutuhan akan kekuasaan yang merupakan refleksi dari dorongan untuk mencapai otoritas untuk memiliki pengaruh terhadap orang lain. 
Menurut Mangkunegara (2006: 76) bahwa: "Seseorang yang mempunyai motivasi berprestasi tinggi akan mencapai kinerja yang tinggi, dan sebaliknya mereka yang kinerjanya rendah disebabkan karena motivasi kerjanya rendah".

Penelitian dari Anita Nurhayati tentang Pengaruh Budaya Organisasi dan Kompetensi terhadap Motivasi dan Dampaknya Terhadap Kinerja Guru di SMP Negeri 16 Bandung. (2012), menunjukkan bahwa terdapat pengaruh yang signifikan dari budaya organisasi terhadap motivasi, kompetensi terhadap motivasi, Budaya organisasi dan kompe-tensi terhadap motivasi, Budaya organisasi terhadap kinerja, kompetensi terhadap kinerja, Motivasi terhadap kinerja, budaya organisasi, kompetensi, dan motivasi terhadap kinerja.

\section{Metode Penelitian (Methodology)}

\section{a. Metode dan Variabel Penelitian}

Penelitian ini menggunakan metode survey deskriptif dan verifikatif yang merupakan "suatu proses penyelidikan yang diadakan untuk memperoleh fakta-fakta dari gejala-gejala yang ada dan mencari keterangan-keterangan secara faktual, baik tentang institusi sosial, ekonomi, atau politik dari suatu kelompok ataupun suatu daerah" (Nazir, 2011: 56).

Penelitian kuantitatif dengan metode deskriptif dan verifikatif pada dasarnya bersifat menguji kebenaran dari suatu hipotesis melalui pengumpulan data dari lapangan. Sehingga apabila kebenaran telah terungkap maka dapat digunakan sebagai bahan dalam memecahkan masalah, karena penelitian itu dilakukan berangkat dari permasalahan yang ditemukan atau dirasakan perlu segera dicarikan alternatif pemecahannya.

Adapun variabel, dimensi dan indikator pengukurnya di definisikan berikut ini.

Tabel 1. Operasional Variabel Penelitian

\begin{tabular}{|c|c|c|}
\hline Variabel & Defenisi Konsep & Indikator \\
\hline $\begin{array}{l}\text { Budaya organisasi } \\
\text { (X1) }\end{array}$ & $\begin{array}{l}\text { Budaya organisasi merupakan suatu system nilai, } \\
\text { kepercayaan dan kebiasaan dalam suatu organisasi, yang } \\
\text { saling berin-teraksi dengan struktur system formalnya } \\
\text { untuk menghasilkan norma-norma perilaku organi-sasi } \\
\text { (Sarplin dalam Asri Laksmi Riyani, 2011:11-12). }\end{array}$ & $\begin{array}{l}\text { a. Lingkungan } \\
\text { b. Nilai-nilai } \\
\text { c.Keteladanan } \\
\text { d.Upacara } \\
\text { e.Network (jaringan) }\end{array}$ \\
\hline $\begin{array}{l}\text { Kompetensi } \\
\left(\mathrm{X}_{2}\right)\end{array}$ & $\begin{array}{l}\text { Kompetensi merupakan seperangkat pengetahuan, } \\
\text { keterampilan dan perilaku yang harus dimiliki, di-hayati, } \\
\text { dikuasai dan diaktua-lisasikan oleh guru dalam } \\
\text { melaksanakan tugas kepro-fesionalan. (Peraturan peme- } \\
\text { rintah No.74 tahun 2008, Pasal 1-2 tentang Guru) }\end{array}$ & $\begin{array}{l}\text { a. Kompetensi kepribadia } \\
\text { b. Kompetensi sosial } \\
\text { c. Kompetensi pedagogik } \\
\text { d. Kompetensi profesional }\end{array}$ \\
\hline $\begin{array}{l}\text { Motivasi } \\
\left(\mathrm{X}_{3}\right)\end{array}$ & $\begin{array}{l}\text { Motivasi merupakan kesediaan untuk mengeluarkan tingkat } \\
\text { upaya yang tinggi untuk tujuan organisasi yang } \\
\text { dikondisikan oleh kemam-puan upaya itu, untuk meme- } \\
\text { nuhi beberapa kebutuhan individual (David McClelland } \\
\text { dalam Mangkunegara, 2004:166) }\end{array}$ & $\begin{array}{l}\text { a. Motivasi prestasi } \\
\text { b.Motivasi afiliasi } \\
\text { c.Motivasi kekuasaan }\end{array}$ \\
\hline $\begin{array}{l}\text { Kinerja Guru } \\
\text { (Y) }\end{array}$ & $\begin{array}{l}\text { Kinerja atau unjuk kerja dalam konteks profesi guru adalah } \\
\text { kegiatan yang meliputi perencanaan, pembelajaran, } \\
\text { pelaksanaan pembelajaran, pelaksanaan pembelajaran/ } \\
\text { KBM dan melakukan penilaian hasil belajar (Surya } \\
\text { Dharma, 2009:36) }\end{array}$ & $\begin{array}{l}\text { a. Perencanaan pembelaja-ran } \\
\text { b. Pelaksanaan KBM } \\
\text { c. Pengevalu-asian hasil belajar }\end{array}$ \\
\hline
\end{tabular}

\section{b. Populasi dan Sampel Penelitian}

populasi dalam penelitian ini seluruh guru SMA Negeri Kecamatan Samalanga Kabupaten Bireuen yang berjumlah 50 orang dan tercatat pada tahun ajaran 2019/2020. Oleh karena jumlah populasi terbatas, maka semua unit dijadikan sampel penelitian, dikenal dengan sampel jenuh.

\section{c. Alat Analisis}

Metode analisis data menggunakan pendekatan Analisis Jalur (Path Analysis) perhitungan koefisien jalur pengaruh langsung. Sebelum dilakukan analisis data atau perhitungan statistic terlebih dahulu dilakukan uji asumsi normalitas, uji linearitas, uji autokorelasi dan uji multikolonieritas. Keempat uji tersebut meupakan persyaratan sebelum melakukan embuktian terhadap hipotesis penelitian. Hal ini merupakan bagian dari statistic inferensial tipe parametris hanya dapat digunakan jika persyaratan analisis terpenuhi. 
Alasan menggunakan analisis jalur karena metode ini dapat menganalisis pola hubungan kausal antara variabel dengan tujuan untuk mengertahui pengaruh langsung dan tidak langsung, secara serempak atau bersama-sama dan parsial atai mandiri, beberapa variabel penyebab terhadap sebuah variabel akaibat.

Analisis jalur meupakan bagian dari model regresi yang dapat digunakan untuk menganalisis hubungan sebab akbat antar saru variabel dengan variabel lainnya. Dalam analisis jalur pengaruh independen dan dependen dapat berupa pengaruh langsung dan pengaruh tdak langsung (direct indirect effect), atau dengan akta lain analysis jalur memperhitungkan adanya pengaruh langsung dan tidak langsung. Pengaruh tidak langsung suatu independent variabel terhadap dependent variabel adalah melalui yang lain disebut variabel antara atau mediasi (intervening variable). Untuk menggambarkan hubungan-hubungan kausal antar variabel yang akan diteliti pada penelitian ini digunakan diagram jalur (path diagram). Diagram jalur (path diagram)adalah alat untuk melukiskan secara grafis, struktur hubungan kausalitas antara variabel eksogen (independen) dan variabel endogen (dependen), adalah berikut ini:

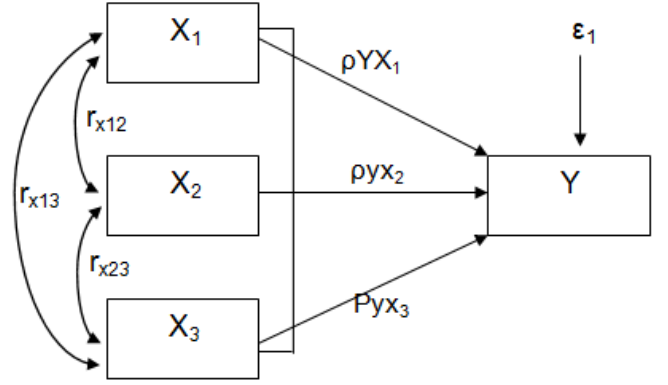

Gambar 1. Analisis Jalur
Keterangan :

$\mathrm{X}_{1}$ : Budaya Organisasi Sekolah

$\mathrm{X}_{2}$ : Kompetensi guru

$\mathrm{X}_{3} \quad$ : Motivasi guru

$\mathrm{Y} \quad$ : Kinerja Guru

$r_{12}$ : Hubungan asosiatif antara X1 dengan X2.

$r_{23}$ : Hubungan asosiatif antara X2 dengan X3.

$\mathrm{r}_{13}$ : Hubungan asosiatif antara X1dengan X3.

$\rho y x_{1}$ : Struktur parameter yang menghubungkan variabel $\mathrm{X}_{1}$ dengan $\mathrm{Y}$

$\rho y x_{2}$ : Struktur parameter yang menghubungkan variabel $\mathrm{X}_{2}$ dengan $\mathrm{Y}$

$\rho y x_{3}$ : Struktur parameter yang menghubungkan variabel $\mathrm{X}_{3}$ dengan $\mathrm{Y}$

$\varepsilon \quad$ : Epsilon, yaitu menunjukan variabel atau faktor residual yang menjelaskan pengaruh variabel lain yang telah teridentifikasi oleh teori, namun tidak diteliti atau variabel lainnya yang belum teridentifikasi oleh teori, atau muncul sebagai akibat dari kekeliruan pengukuran variabel.

\section{Hasil dan Pembahasan (Results and Discussion)}

\section{a. Karakteristik Responden}

Responden dalam penelitian ini berjumlah 50 orang guru di SMA Negeri di Kecamatan Samalanga Kabupaten Bireuen, dengan karakteristik responden adalah:

Tabel 2. Karakteristik Responden Berdasarkan Jenis Kelamin

\begin{tabular}{|c|c|c|}
\hline Karateristik & Jumlah (orang) & Persentase (\%) \\
\hline Kelamin : Laki-laki & 9 & 18 \\
\hline Perempuan & 41 & 82 \\
\hline Umur : 30 & 5 & 10,00 \\
\hline $31-40$ & 6 & 12,00 \\
\hline $41-50$ & 18 & 36,00 \\
\hline$>50$ & 21 & 42,00 \\
\hline Masa kerja (Thn): $<5$ & 3 & 6,00 \\
\hline $6-10$ & 6 & 12,00 \\
\hline $11-15$ & 10 & 20,00 \\
\hline $16-20$ & 12 & 24,00 \\
\hline$>20$ & 19 & 38,00 \\
\hline Pendidikan: S1 (Sarjana) & 50 & 100 \\
\hline S2/S3 (Pascasarjana) & 0 & 0 \\
\hline Total & $\mathbf{6 0}$ & $\mathbf{1 0 0}$ \\
\hline
\end{tabular}

Sumber : SMA Negeri di Kecamatan Samalanga Kabupaten Bireuen, 2020

\section{b. Hasil analisis Deskriptif}

Analisis deskriptif akan menunjukkan gambaran mengenai suatu data yang akan diteliti atau untuk menguraikan kecenderungan jawaban responden dari tiap-tiap variabel. Berdasarkan hasil kuesioner yang telah teruji validitas dan reliabilitasnya, dari 50 guru pada SMAN di Kecamatan Samalanga Kabupaten Bireuen diperoleh jawaban terhadap variabel bebas Budaya organisasi, Kompetensi, Motivasi kerja dan variabel Kinerja guru sebagai berikut. 
Tabel 3. Deskripsi Guru tentang Variabel Penelitian

\begin{tabular}{|c|c|c|c|c|c|c|c|c|}
\hline \multirow{2}{*}{\multicolumn{3}{|c|}{ Variabel }} & \multicolumn{5}{|c|}{ Persentase Jawaban } & \multirow{2}{*}{$\begin{array}{c}\text { Skor } \\
\text { Pencapaian }\end{array}$} \\
\hline & & & STS & TS & KS & $\mathbf{S}$ & SS & \\
\hline 1. & Budaya organis & : (12 butir) & 0,00 & 1,33 & 5,00 & 46,67 & 47,00 & 87,87 \\
\hline 2. & Kompetensi & $:$ (12 butir) & 0,17 & 0,83 & 5,83 & 56,00 & 37,17 & 85,83 \\
\hline 3. & Motivasi kerja & : (11 butir) & 0,17 & 0,00 & 6,17 & 48,67 & 28,33 & 85,13 \\
\hline 4. & Kinerja Guru & $:$ (16 butir) & 0,00 & 0,33 & 8,67 & 76,17 & 48,17 & 85,83 \\
\hline
\end{tabular}

Sumber : Hasil Peneltian, 2020 (data diolah, dengan SPSS)

Berdasarkan tabel di atas dapat dijelaskan bahwa :

1) Variabel Budaya organisasi termasuk baik dalam mendukung kinerja guru guru. Skor penilaian guru atas budaya sekolah mencapai $87,87 \%$

2) Variabel Tingkat Kompetensi guru, sudah baik mencapai 85,83\% dari kondisi yang ideal,

3) Motivasi kerja guru sudah menunjukkan hal yang baik, mencapai $85,13 \&$ dari yang diharapkan untuk meningkatkan kinerja guru, dan

4) Tingkat kinerja guru sudah mencapai kategori sangat baik, yakni $85,83 \%$, walaupun masih bisa dioptimalkan lagi.

\section{c. Hasil Analisis Jalur}

Dalam penelitian ini model analisis dengan analisi jalur yang menentukan pengaruh variabel Budaya organisasi $\left(\mathrm{X}_{1}\right)$, Kompetensi $\left(\mathrm{X}_{2}\right)$, dan Motivasi guru $\left(\mathrm{X}_{3}\right)$ terhadap Kinerja guru $(\mathrm{Y})$. Dengan model $\mathrm{Y}=$ $f(X 1, X 2, X 3)=\rho_{1} X_{1}+\rho_{2} X_{2}+\rho_{3} X_{3}+$ e. Adapun pembuktian hipotesis secara simultan dapat dilihat pada tabel berikut ini:

Tabel 4. Uji Model Sruktural (Uji Secara Simultan)

\begin{tabular}{|c|c|c|c|c|c|}
\hline Model & Sum of Squares & $\mathrm{df}$ & Mean Square & $\mathrm{F}$ & Sig. \\
\hline Regression & 2318.974 & 3 & 772.991 & 25.663 & $.000^{\mathrm{a}}$ \\
\hline Residual & 1385.586 & 46 & 30.121 & & \\
\hline Total & 3704.560 & 49 & & & \\
\hline
\end{tabular}

a. Predictors: (Constant), X3, X1, X2

b. Dependent Variable: Z

Sumber: Data olahan, 2020 (diolah dengan SPSS)

Berdasarkan hasil uji $F$ diperoleh nilai $F_{\text {hitung }}$ sebesar 25,663. Sementara nilai signifikansinya 0,000. Hal ini menunjukkan model regresi antar variabel signifikansi linier. Maka model analisi jalur dalam bentuk $\mathrm{Y}=$ $f(X 1, X 2, X 3)=\rho_{1} X_{1}+\rho_{2} X_{2}+\rho_{3} X_{3}$ diterima.

\section{1). Pengujian Hipotesis Penelitian}

Dalam hal ini hipotesis yang diajukan selanjutnya diuji untuk menjawab masalah penelitian yang dirumuskan, yakni:

Hipotesis-1:

Ho: $\rho_{\mathrm{zx} 1} \leq 0$ : Budaya Organisasi tidak berpengaruh terhadap Kinerja guru

$\mathrm{H}_{1}: \rho_{\mathrm{zx} 1}>0$ : Budaya Organisasi berpengaruh terhadap Kinerja guru

Kriteria pengujian adalah total Ho jika $t_{\text {hitung }}>t_{\text {tabel }}$ dimana $t_{\text {tabel }}$ untuk $\alpha=5 \%$ adalah 1,645. Hipotesis ini menyatakan ada pengaruh Budaya organisasi $\left(\mathrm{X}_{1}\right)$ terhadap Kinerja guru $(\mathrm{Y})$. Dengan koefisien jalurnya $\rho_{\mathrm{yx} 1}=0,395$. Hasil perhitungan uji individu menunjukkan harga $t_{\text {hitung }}$ sebesar 4,022. Dengan demikian $t_{\text {hitung }}$ $>\mathrm{t}_{\text {tabel }}(4,022>1,645)$. Sehingga Ho ditolak dan $\mathrm{H}_{1}$ diterima artinya koefisien jalur Budaya organisasi $\left(\mathrm{X}_{1}\right)$ terhadap Kinerja guru (Y). dapat dinyatakan signifikan pada taraf signifikan $\alpha=0,05$. Dengan demikian dapat dinyatakan bahwa Budaya organisasi sekolah dapat mempengaruhi secara langsung terhadap Kinerja guru pada SMAN di kecamatan Samalangan Bireuen, yang teruji secara empiris.

Hipotesis 2

Ho: $\rho_{\mathrm{yx} 2} \leq 0$ : Kompetensi tidak berpengaruh terhadap Kinerja guru

$\mathrm{H}_{1}: \rho_{\mathrm{yx} 2}>0$ : Kompetensi berpengaruh terhadap Kinerja guru

Hipotesis ini menyatakan ada pengaruh Kompetensi $\left(\mathrm{X}_{2}\right)$ terhadap Kinerja guru $(\mathrm{Y})$. Dengan koefisien jalurnya $\rho_{\mathrm{yx} 2}=0,332$. Hasil perhitungan uji individu menunjukkan harga $\mathrm{t}_{\text {hitung }}$ sebesar 3,047 Dengan demikian $t_{\text {hitung }}>t_{\text {tabel }}(3,047>1,645)$. Sehingga Ho ditolak dan H1 diterima, yang artinya koefisien jalur variabel Kompetensi $\left(\mathrm{X}_{2}\right)$ terhadap Kinerja guru $(\mathrm{Y})$, dapat dinyatakan signifikan pada taraf signifikan $\alpha=$ 
0,05. Dengan demikian dapat dinyatakan bahwa variabel Kompetensi dapat mempengaruhi secara langsung terhadap Kinerja guru (Y). pada SMAN di Kecamatan Samalangan Bireuen, yang teruji secara empiris.

Hipotesis 3

Ho: $\rho_{\mathrm{yz} 3} \leq 0$ : Motivasi guru tidak berpengaruh terhadap Kinerja guru

$\mathrm{H}_{1}: \rho_{\mathrm{yx} 3}>0$ : Motivasi guru berpengaruh terhadap Kinerja guru

Hipotesis ini menyatakan ada pengaruh Motivasi gutu tidak berpengaruh terhadap Kinerja guru $(\mathrm{Y})$. Dengan koefisien jalurnya $\rho_{\text {zyx } 3}=0,292$. Hasil perhitungan uji individu menunjukkan harga $\mathrm{t}_{\text {hitung }}$ sebesar 2,626. Dengan demikian $t_{\text {hitung }}>t_{\text {tabel }}(2,626>1,645)$. Sehingga Ha diterima artinya koefisien jalur variabel Motivaso guru $\left(\mathrm{X}_{3}\right)$ terhadap Kinerja guru (Y), dapat dinyatakan signifikan pada taraf signifikan $\alpha=0,05$.

Dengan demikian dapat dinyatakan bahwa variabel Motivasi guru dapat mempengaruhi secara langsung terhadap Kinerja guru pada SMAN di Kecamatan Samalangan Bireuen, yang teruji secara empiris.

\section{2). Menentukan Model Struktural}

Setelah terbukti adanya hubungan dan pengaruh secara signifikans anatara variabel eksogen terhadap variabel endogen dalam penelitian ini, lalu dilakukan taksiran nilai kausalitas antar variabel eksogen $\left(\mathrm{X}_{1}\right.$, $\mathrm{X}_{2}, \mathrm{X}_{3}$ ) pada tabel 5, dan taksiran koefisien jalur pada tabel 6, yakni :

Tabel 5. Hubungan Kausal Antar Variabel Bebas (Eksogenus)

\begin{tabular}{|l|l|c|c|c|}
\hline & & Budaya Organisasi & Kompetensi & Motivasi \\
\hline \multirow{4}{*}{ Budaya Organisasi } & Pearson Correlation & 1 & $.320^{*}$ & $.369^{* *}$ \\
\cline { 2 - 5 } & Sig. (2-tailed) & & .024 & .008 \\
\cline { 2 - 5 } & $\mathrm{N}$ & 50 & 50 & 50 \\
\hline \multirow{3}{*}{ Kompetensi } & Pearson Correlation & $.320^{*}$ & 1 & $.547^{* *}$ \\
\cline { 2 - 5 } & Sig. (2-tailed) & .024 & & .000 \\
\cline { 2 - 5 } & $\mathrm{N}$ & 50 & 50 & 50 \\
\hline \multirow{3}{*}{ Motivasi } & Pearson Correlation & $.369^{* *}$ & $.547^{* *}$ & 1 \\
\cline { 2 - 5 } & Sig. (2-tailed) & .008 & .000 & 50 \\
\cline { 2 - 5 } & $\mathrm{N}$ & 50 & 50 & \\
\hline
\end{tabular}

*. Correlation is significant at the 0.05 level (2-tailed).

**. Correlation is significant at the 0.01 level (2-tailed).

Lalu ditaksir nilai koefisien jalur antar variabel eksogen $\left(\mathrm{X}_{1}, \mathrm{X}_{2}, \mathrm{X}_{3}\right)$ terhadap variabel endogen $(\mathrm{Y})$, dengan hasilnya sebagai berikut:

Tabel 6. Taksiran Nilai Koefisien Jalur antar Var-Eksogenus dan Endogen

\begin{tabular}{|l|l|c|c|}
\hline \multirow{2}{*}{ Model } & Standardized Coefficients & \multirow{2}{*}{} & \multirow{2}{*}{ Sig. } \\
\cline { 2 - 3 } & Beta & $\mathrm{t}$ & .833 \\
\hline \multirow{2}{*}{ (Constant) } & & -.212 & .000 \\
\cline { 2 - 3 } Budaya Organisasi (X1) & .395 & 4.022 & .004 \\
\hline Kompetensi (X2) & .332 & 3.047 & .012 \\
\hline
\end{tabular}

$\mathrm{Y}=$ Kinerja Guru

Sumber: Data Primer, 2020 (diolah pada Lampiran-9)

Berdasarkan antar variabel eksogen, dan nilai koefisien jalur ( $\rho$ ), maka model kausal yang dibentuk secara teoritik diperoleh diagram jalur seperti gambar 2 . 

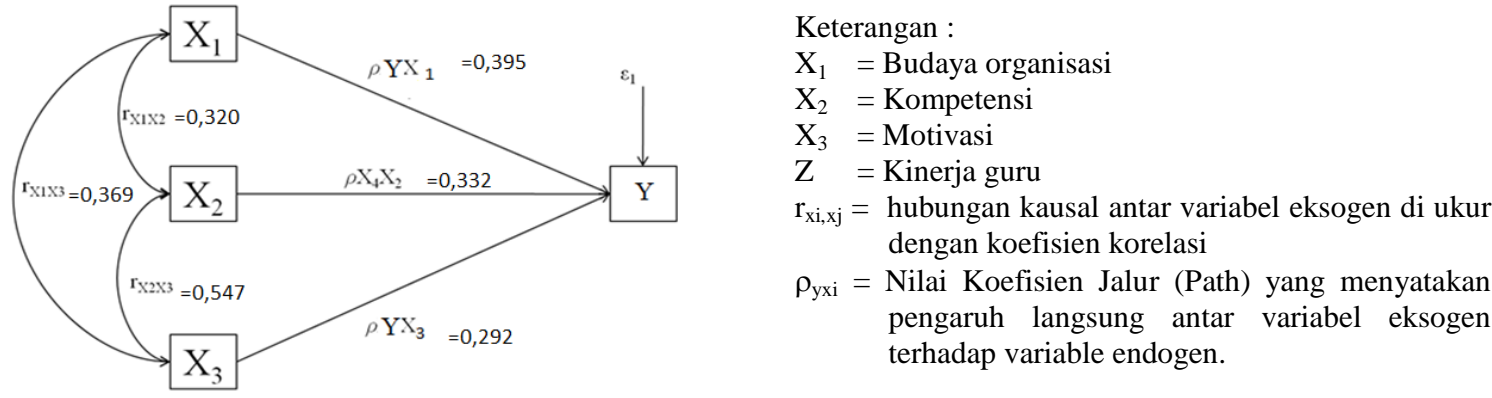

\section{d. Pembahasan}

\section{1). Pengaruh Budaya Organisasi terhadap Kinerja Guru}

Hasil analisis data sebelumnya, menunjukkan adanya pengaruh Budaya organisasi sekolah terhadap Kinerja guru. Adapun besarnya pengaruh, langsung ataupun tidak langsung karena terdapat hubungan kausalitas antara variabel Budaya Organissi dengan kompetensi serta Motivasi guru, ditentukan berikut ini:

Besarnya pengaruh langsung Budaya organisasi $\left(\mathrm{X}_{1}\right)$ terhadap Kinerja guru $(\mathrm{Y})$, dinyatakan dengan besaran koefisien jalur $\left(\rho_{z \times 1}=0,395\right)$, Sehingga besarnya pengaruh langsung ini adalah: $16,60 \%$.

Besarnya pengaruh tak langsung Budaya organisasi $\left(\mathrm{X}_{1}\right)$ terhadap Kinerja guru $(\mathrm{Y})$, karena adanya hubungan kausal dalam variabel eksogen, sehingga di hitung sebagai berikut:

-Pengaruh Budaya organisasi dan kompetensi terhadap Kinerja, adalah: $(0,395)(0,320)(0,332) \times 100 \%=4,20 \%$

-Pengaruh Budaya organisasi dan motivasi guru terhadap Kinerja, adalah: $(0,395)(0,369)(0,292) \times 100 \%=4,26 \%$ Maka Pengaruh Total Budaya organisasi $\left(\mathrm{X}_{1}\right)$ terhadap Kinerja guru adalah 25,06 persen.

\section{2). Pengaruh Kompetensi terhadap Kinerja Guru}

Hasil analisis data sebelumnya, menunjukkan adanya pengaruh kompetensi terhadap Kinerja guru. Adapun besarnya pengaruh, langsung ataupun tidak langsung karena terdapat hubungan kausalitas antara variabel Kompetensi, dengan Budaya organisasi dan Motivasi guru, ditentukan berikut ini:

Besarnya pengaruh langsung Kompetensi $\left(\mathrm{X}_{2}\right)$ terhadap Kinerja guru $(\mathrm{Y})$, dinyatakan dengan besaran koefisien jalur $\left(\rho_{\mathrm{yx} 2}=0,332\right)$, Sehingga besarnya pengaruh langsung ini adalah: $11,02 \%$.

-Pengaruh tak langsung Kompetensi terhadap Kinerja guru (Y) di hitung sebagai berikut:

-Pengaruh Kompetensi dan Budaya terhadap Kinerja guru (Y), adalah: $(0,332)(0,320)(0,395) \times 100 \%=4,20 \%$

-Pengaruh Kompetensi dengan motivasi terhadap Kinerja guru, adalah: $(0,332)(0,547)(0,292) \times 100 \%=5,30 \%$

Maka Pengaruh Total Kompetensi $\left(\mathrm{X}_{2}\right)$ terhadap Kinerja guru SMA Samalanga Kabupaten Bireuen $(\mathrm{Y})$ adalah 50,52 persen.

\section{3). Pengaruh Motivasi guru terhadap Kinerja Guru}

Hasil analisis data sebelumnya, menunjukkan adanya pengaruh Motivasi guru terhadap Kinerja guru. Adapun besarnya pengaruh langsung ataupun tidak langsung karena terdapat hubungan kausalitas antara variabel motivasi dengan Budaya organisasi dan kompetensi terhadap Kinerja guru, ditentukan berikut ini:

Besarnya pengaruh langsung Motivasi guru $\left(\mathrm{X}_{3}\right)$ terhadap Kinerja guru $(\mathrm{Y})$, dinyatakan dengan besaran koefisien jalur $\left(\rho_{\mathrm{yx} 2}=0,292\right)$, Sehingga besarnya pengaruh langsung ini adalah: $8,53 \%$.

Pengaruh tak langsung motivasi guru $\left(\mathrm{X}_{3}\right)$ terhadap Kinerja guru $(\mathrm{Y})$ di hitung sebagai berikut: -Pengaruh motivasi dan budaya sekolah terhadap Kinerja guru, adalah: $(0,292)(0,369)(0,395) \times 100 \%=4,26 \%$ -Pengaruh Motivasi dan kompetensi terhadap Kinerja guru, adalah: $(0,292)(0,547)(0,332) \times 100 \%=5,30 \%$ Maka pengaruh Total Motivasi guru $\left(\mathrm{X}_{3}\right)$ terhadap Kinerja guru SMA Samalanga Kabupaten Bireuen $(\mathrm{Y})$, adalah dengan 18,09 persen.

\section{4). Pengaruh Budaya Organisasi, Kompetensi dan Motivasi guru terhadap Kinerja Guru SMA Negeri di Kecamatan Samalanga Kabupaten Bireuen}

Berdasarkan model struktural yang dikaji dan dibahas sebelumnya, maka dapat di perdalam dengan melibatkan ketiga faktor yang diduga berpengaruh pada kinerja guru, yakni faktor Budaya Organisasi, Kompetensi dan Motivasi guru, dengan terhadap Kinerj guru secara simultan, yakni dengan menghitung korelasi dan determinasi antar variabel ini, yakni sebagai berikut: 
a). Korelasi antar Budaya Organisasi, Kompetensi dan Motivasi guru, dengan terhadap Kinerja guru secara simultan

Berdasarkan hitungan korelasi dan determinasi antar variabel Budaya Organisasi, Kompetensi dan Motivasi guru, terhadap Kinerja guru, sebagaimana ditunjukkan dalam table berikut :

Tabel 7. Korelasi dan Determinasi antar variabel

\begin{tabular}{|r|r|r|r|}
\hline R & R Square & Adjusted R Square & Std. Error of the Estimate \\
\hline $.791^{\mathrm{a}}$ & .626 & .602 & 5.488299 \\
\hline
\end{tabular}

Maka dari informasi diatas, terdapat sebesar 0,791 korelasi antar variabel Budaya Organisasi, Kompetensi dan Motivasi guru, dengan terhadap Kinerja guru. Ini menunjukkan hubungan yang kuat dengar derajat 0,791 dan hubungan nya positip.

Dan Hasil koefsiein determinasinya $\left(\mathrm{R}^{2}\right)$ adalah sebesar 0,626 yang dimaknai bahwa terdapat sebesar 62,6 $\%$ kontribusi atau peranan adanya faktor Budaya Organisasi, Kompetensi dan Motivasi guru, dalam meningkatkan Kinerja guru. Dan sisanya yakni sekitar 37,4 \% dipengaruhi oleh faktor lain, seperti kompensasi, gaya kepemimpinan kepala sekolah, fasilitas, pelatihan guru, atau lainnya yang mengikat terhadap kinerja guru.

\section{Simpulan (Conclusion)}

Sebagaimana tuan dari penelitian ini, maka dari hasil penelitian dan pembahasan yang dilakukan, dapat ditarik beberapa simpulan penting sebagai rangkuman dan temuan hasil penelitian, yakni:

1) Budaya organisasi yang telah dijalankan di sekolah SMA Negeri Kecamatan Samalanga Kabupaen Bireuen, mneurut persepsi guru sudah berjalan baik dalam mendukung kinerja guru. Penilaian guru atas budaya sekolah mencapai $87,87 \%$ telah disesuai dengan harapan guru. Sementara itu tingkat Kompetensi guru yang professional, sesuai dengan Peraturan Pemerintah No.74 tahun 2008, sudah baik mencapai $85,83 \%$ dari kondisi yang ideal. Dan motif guru untuk berprestasi, afiliasi dan kekuasaan dalam mendukung program sekolah yakni peningkatan mutu menunjukkan hal yang baik, mencapai $85,13 \%$ dari yang diharapkan.

2) Tingkat kinerja guru dalam melaksanakan perencanaan pembelajaran, Pelaksanaan KBM maupun melakukan evaluasi hasil belajar sudah mencapai kategori sangat baik, yakni $85,83 \%$ dari target tugas yang ideal.

3) Hasil penelitian verifikatif di dasarkan pada sampel 50 guru yang dijadikan respoden penelitian dengan pendekatan analisis jalur (Path Analysis), diperoleh suatu pembuktian nyata bahwa

a) Terdapat pengaruh yang signifikans faktor budaya organisasi sekolah terhadap Kinerja guru. Adapun besarnya sebesar $25,06 \%$.

b) Terdapat pengaruh yang signifikans faktor kompetensi guru terhadap Kinerja guru. Dengan total pengaruhnya sebesar $50,52 \%$.

c) Terdapat pengaruh yang signifikans faktor motivasi guru untuk berprestsi dan berafiliasi terhadap Kinerja guru, sebesar $18,09 \%$.

d) Dan secara bersama-sama pengaruh Budaya Organisasi, Kompetensi dan Motivasi guru, terhadap Kinerja guru diperoleh dari nilai determinasi antar variabel ini, yakni sebesar $62,6 \%$. Dan sisanya yakni sekitar 37,4 \% dipengaruhi oleh faktor lain, seperti kompensasi, gaya kepemimpinan kepala sekolah, fasilitas, pelatihan guru, atau lainnya yang mengikat terhadap kinerja guru.

\section{DAFTAR PUSTAKA (References)}

1) A.A. Anwar Prabu Mangkunegara. 2007, Manajemen Sumber Daya Manusia,. Cetakan Ke Tujuh, Bandung: PT. Remaja Rosdakarya.

2) Asri Laksmi Riani, M. 2011. Perspektif Kompensasi. Surakarta: Yuma Pustaka

3) Agustini, Fauzia. 2012. Pengantar Manajemen Sumber Daya Manusia (MSDM1). Medan Madenatera.:

4) Andi Saputra, 2008, Pengaruh kualitas pelayanan dan kepuasan pelanggan terhadap loyalitas pelanggan pada PT. Sinar Lestari Mestika di Pekanbaru. Skripsi, UNRI Pers Pekanbaru.

5) Anita Nurhayati, 2012. Pengaruh Budaya Organisasi dan Kompetensi terhadap Motivasi dan Dampaknya Terhadap Kinerja Guru di SMP Negeri 16 Bandung. Penelitian

6) Azwar, Saifuddin.2004. Metode Penelitian.Yogyakarta: Pustaka Pelajar. 
7) Conny,Semiawan.2010.Lingkungan Keluarga Yang Mempengaruhi Motivasi Belajar

8) Dharma, Surya. 2009. Manajemen Kinerja Falsafah Teori dan. Penerapannya, Pustaka Pelajar, Yogyakarta:

9) Depdiknas. 2008. Penilaian Kinerja Guru. Jakarta: Ditjen PMPTK

10) E.Mulyasa, 2007. Standar Kompetensi dan Sertifikasi Guru. Bandung: PT. Remaja. Rosdakarya.

11) Ilyas, yaslis. 1999. Kinerja : Teori, Penilaian, dan Penelitian. Jakarta : Badan. Penerbit FKM UI. Indonesia

12) Judge, T. A., \& Colquitt, J. A. 2004. Organizational justice and stress: The mediating role of workfamily conflict. Journal of Applied Psychology,. 89(3), 395.

13) Luthans, Fred. 2011. Organizational Behavior: An Evidence-Based Approach. New York: McGrawHill

14) Muhammad Rizal Saragih, 2017. Pengaruh Budaya Organisasi, Kompetensi Guru Dan Motivasi Terhadap Kinerja Guru SDN Joglo 05 Pagi Jakarta, http://openjournal.unpam.ac.id/index.php/Inovasi/article/view/754

15) Nazir.Mohammad,Ph.D.2011. Metode Penelitian. Jakarta : Ghalia Indonesia Rani Mariam, 2009, Pengaruh Gaya Kepemimpinan Dan Budaya Organisasi Terhadap Kinerja Karyawan Melalui Kepuasan Kerja Karyawan Sebagai Variabel Intervening Studi Pada Kantor Pusat PT.Asuransi Jasa Indonesia (Persero), Tesis, Universitas Diponegoro Semarang

16) Robbins, P. Stephen. 2008. Organizational Behaviour, Tenth Edition (Perilaku Organisasi Ke Sepuluh), alih bahasa Drs. Benyamin Molan. Salemba Empat: Jakarta.

17) Supardi. 2013. Aplikasi Statistika dalam Penelitian Konsep Statistika yang Lebih Komprehensif. Jakarta: Change Publication.

18) https://www.ceritabumi.com/sma-terbaik-aceh tertanggal 30 Maret 2019. 